\title{
Irrigation Water and Nitrate-nitrogen Loss Characterization in Southern Florida Nurseries: Cumulative Volumes, Runoff Rates, Nitrate- nitrogen Concentrations and Loadings, and Implications for Management
}

\author{
Chris Wilson ${ }^{1,3}$, Joseph Albano ${ }^{2}$, Miguel Mozdzen ${ }^{1}$, and \\ Catherine Riiska ${ }^{1}$
}

\begin{abstract}
AdDitionAL INDEX wORDs. water quality, nutrient enrichment, leaching, container production, bedding plants, foliage plants, bioremediation

SUMMARY. Enrichment of surface water with nitrate-nitrogen $\left(\mathrm{NO}_{3}-\mathrm{N}\right)$ is a significant problem throughout the world. In support of developing a method for removing $\mathrm{NO}_{3}-\mathrm{N}$ from water using denitrification, this project characterized runoff events at two nurseries in southern Florida to provide information needed for designing capacity. Specifically, estimates of runoff rates and volumes, $\mathrm{NO}_{3}-\mathrm{N}$ concentrations and loadings were profiled during intensively sampled fertigation events at a foliage plant nursery and a bedding plant nursery. Discharge volumes and rates varied with event, ranging from 2,487 to $20,935 \mathrm{~L}$ and 59.2 to $126 \mathrm{~L} \cdot \mathrm{min}^{-1}$, respectively, per event. $\mathrm{NO}_{3}-\mathrm{N}$ concentrations ranged from 0.7 to $386.4 \mathrm{mg} \cdot \mathrm{L}^{-1}$, and event loadings ranged from 51 to $3024 \mathrm{~g}$, indicating that significant losses may be realized. This project provided valuable hydraulic and chemical loading information needed for the development and design of bioremediation tools for the horticultural industry.
\end{abstract}

A pplications of nitrogen $(\mathrm{N})$ are essential for producing quality ornamental plants. Nitrate-N typically is applied in soluble or controlled-release, commercially available fertilizer products. Nitrate readily dissolves in water due to the salt's ionic structure and has a high potential for moving with water once dissolved. Leaching of $\mathrm{NO}_{3}$ from containers is enhanced by the low anion-holding capacity of most media used for plant production.

Much research has focused on documenting leaching of $\mathrm{NO}_{3}-\mathrm{N}$ from containerized nursery crops. Bigelow et al. (2001) reported leaching of more than $95 \%$ of $\mathrm{NO}_{3}-\mathrm{N}$ applied in studies where sand-based soils were incorporated with inorganic and organic amendments such as sphagnum peat. Colangelo and Brand (2001) reported average annual flowweighted nitrate $\left(\mathrm{NO}_{3}\right)$ concentrations in leachates from controlled-releasefertilized, containerized 'Album' rhododendron (Rbododendron catawbiense) crops of $7.2 \mathrm{mg} \cdot \mathrm{L}^{-1}$ for overhead irrigation and $12.7 \mathrm{mg} \cdot \mathrm{L}^{-1}$ for trickle irrigation. Merhaut et al. (2006) evaluated release characteristics of four types of controlled-release fertilizers over a 47 -week simulated production cycle. They reported that $\mathrm{NO}_{3}-\mathrm{N}$ concentrations in leachates were often greater than $10 \mathrm{mg} \cdot \mathrm{L}^{-1}$, which is the U.S. Environmental Protection Agency (USEPA) drinking water standard. Other studies have documented nutrient enrichment of surface water on a larger nursery-scale. Alexander (1993) reported $\mathrm{NO}_{3}-\mathrm{N}$ concentrations ranging from 1.6 to $55 \mathrm{mg} \cdot \mathrm{L}^{-1}$. Mangiafico et al. (2009) reported mean $\mathrm{NO}_{3}-\mathrm{N}$ concentrations in runoff from nurseries in southern California of $15.6 \mathrm{mg} \cdot \mathrm{L}^{-1}$. Likewise, Yeager et al. (1993) surveyed $\mathrm{NO}_{3}-\mathrm{N}$ concentrations in nursery runoff and collection pond water in six states. They reported concentrations ranging from 0.5 to $33 \mathrm{mg} \cdot \mathrm{L}^{-1}$ in runoff water from production beds using controlled-release fertilizer, and 0.1 to $135 \mathrm{mg} \cdot \mathrm{L}^{-1}$ in beds using a combination of controlled-release and soluble fertilizers (Yeager et al., 1993). $\mathrm{NO}_{3}-\mathrm{N}$ concentrations in collection ponds were as high as $23 \mathrm{mg} \cdot \mathrm{L}^{-1}$ (Yeager et al., 1993). Taylor et al. (2006) reported $\mathrm{NO}_{3}-\mathrm{N}$ concentrations in nursery runoff water ranging from 11.1 to $29.9 \mathrm{mg} \cdot \mathrm{L}^{-1}$ during the spring fertilization period, and 2.8 to $5.2 \mathrm{mg} \cdot \mathrm{L}^{-1}$ during the plant dormancy period in the winter.

Leaching and losses through surface runoff of $\mathrm{NO}_{3}-\mathrm{N}$ from containers and production areas increases production costs and reduces the return on finished plants. Enrichment of recycled nursery water with $\mathrm{NO}_{3}-\mathrm{N}$ may also result in increased filter clogging and reservoir maintenance due to increased production of algae and aquatic plants. Additionally, offnursery discharge of $\mathrm{NO}_{3}-\mathrm{N}$-enriched drainage water into $\mathrm{N}$-limited aquatic ecosystems may stimulate many undesirable changes associated with eutrophication, resulting in the loss of desirable aquatic habitats and changes
We gratefully acknowledge financial support for this project from the USDA-ARS Floriculture and Nursery Research Initiative: project number 6618-13000-003-05S "Water Quality Protection Using Bioremediation and Decision Support Technologies."

We thank Ryan Hamm (University of Florida) and Chris Lasser (USDA) for their technical assistance with this project.

${ }^{1}$ University of Florida/IFAS, Indian River Research and Education Center, 2199 South Rock Road, Fort Pierce, FL 34945

${ }^{2}$ U.S. Department of Agriculture, Agricultural Research Service, U.S. Horticultural Research Laboratory, 2001 South Rock Road, Fort Pierce, FL 34945

${ }^{3}$ Corresponding author. E-mail: pcwilson@ufl.edu.

\begin{tabular}{cllc}
\hline $\begin{array}{l}\text { Units } \\
\text { To convert U.S. to SI, } \\
\text { multiply by }\end{array}$ & U.S. unit & SI unit & $\begin{array}{l}\text { To convert SI to U.S., } \\
\text { multiply by }\end{array}$ \\
\hline 0.4047 & $\mathrm{acre}(\mathrm{s})$ & $\mathrm{ha}$ & 2.4711 \\
29,574 & $\mathrm{fl} \mathrm{oz}$ & $\mu \mathrm{L}$ & $3.3814 \times 10^{-5}$ \\
29.5735 & $\mathrm{fl} \mathrm{oz}$ & $\mathrm{mL}$ & 0.0338 \\
3.7854 & $\mathrm{gal}$ & $\mathrm{L}$ & 0.2642 \\
9.3540 & $\mathrm{gal} / \mathrm{acre}$ & $\mathrm{L} \cdot \mathrm{ha}$ & 0.1069 \\
2.54 & $\mathrm{inch}(\mathrm{es})$ & $\mathrm{cm}$ & 0.3937 \\
25.4 & $\mathrm{inch}(\mathrm{es})$ & $\mathrm{mm}$ & 0.0394 \\
0.4536 & $\mathrm{lb}$ & $\mathrm{kg}$ & 2.2046 \\
1.1209 & $\mathrm{lb} / \mathrm{acre}$ & $\mathrm{kg} \cdot \mathrm{ha}$ & 0.8922 \\
28.3495 & $\mathrm{oz}$ & $\mathrm{g}$ & 0.0353 \\
28,350 & $\mathrm{oz}$ & $\mathrm{mg}$ & $3.5274 \times 10^{-5}$ \\
0.001 & $\mathrm{ppm}$ & $\mathrm{g} \cdot \mathrm{L}^{-1}$ & 1000 \\
1 & $\mathrm{ppm}$ & $\mathrm{mg} \cdot \mathrm{L}^{-1}$ & 1
\end{tabular}


to natural ecosystems. In fact, the USEPA and many state governments are developing total maximum daily loads (TMDLs) for $\mathrm{NO}_{3}-\mathrm{N}$ and other nutrients in many watersheds throughout the United States. Ultimately, these TMDLs will limit the amount of $\mathrm{NO}_{3}-\mathrm{N}$ that can be discharged into off-site water bodies. For nurseries that recycle $100 \%$ of their drainage water and rarely discharge water off-site, TMDLs should have minimal impacts. However, for nurseries that must discharge drainage water due to limited onsite storage capacity, strategies will need to be developed for removing $\mathrm{NO}_{3}-\mathrm{N}$ before discharge.

This research project was designed to provide more detailed information on surface water drainage flow rates, volumes, and $\mathrm{NO}_{3}-\mathrm{N}$ losses at the production area scale. While $\mathrm{NO}_{3}-\mathrm{N}$ concentration data are available in the literature, no information is available regarding associated $\mathrm{NO}_{3}{ }^{-}$ $\mathrm{N}$ loading and associated flow rate profiles and volumes during actual runoff events. This information is particularly important for designing a microbial-based, denitrifying bioremediation system with enough capacity for treating realistic volumes of nursery drainage water. The intent was not to exhaustively study all of the factors associated with $\mathrm{NO}_{3}-\mathrm{N}$ leaching and discharge, but to provide more regional estimates for typical losses (concentrations and loads) and discharge volumes/rates from commercial nursery production areas.

\section{Materials and methods}

Site DesCription. Two nurseries located in two Florida counties, St. Lucie and Martin, were selected for investigation of $\mathrm{NO}_{3}-\mathrm{N}$ losses in drainage water (i.e., surface runoff). One nursery [foliage plant nursery $(\mathrm{FPN})]$ produces high-quality foliage plants using fertigation through a drip/microsprinkler irrigation system. This nursery recycles most of its water. Water used to irrigate and fertigate is pumped from a nonlined surface reservoir. Production surfaces are covered with woven landscape fabric underlain by plastic sheeting. The other nursery [bedding plant nursery $(\mathrm{BPN})$ ] produces high-quality bedding plants using an overhead irrigation/fertigation microsprinkler system, coupled with the addition of slow-release fertilizers in the container media. Water used to irrigate and fertigate is pumped from an onsite well, a central collection pond, or both. During storm events, runoff water may leave both nursery sites once the retention ponds reach their storage capacity.

RunOFF EVENTS. Measurements of runoff volume and $\mathrm{NO}_{3}-\mathrm{N}$ loadings in runoff water were monitored during portions of four irrigation/ fertigation events at the FPN (FPN$1,-2,-3$, and -4$)$ and two events at the BPN (BPN-1 and -2). To estimate the total volume of irrigation water applied during each event, three emitters within each irrigation zone were placed in individual 4-L polyethylene containers. The total volume of water applied by each emitter was measured using a graduated cylinder. The average volume applied by the three emitters within each zone was then multiplied by the total number of emitters within the area to estimate total volume applied. Additionally, samples of the collected irrigation water were analyzed for $\mathrm{NO}_{3}-\mathrm{N}$ (analytical methods explained later). The $\mathrm{NO}_{3}-\mathrm{N}$ concentration was multiplied by the volume produced per emitter to estimate total $\mathrm{NO}_{3}-\mathrm{N}$ applied per emitter for the FPN-1, FPN-2, BPN1 , and BPN-2 events. Total $\mathrm{NO}_{3}-\mathrm{N}$ applied to the production area was then calculated by multiplying the total $\mathrm{NO}_{3}-\mathrm{N}$ per emitter by the total number of emitters within the production area. Total $\mathrm{NO}_{3}-\mathrm{N}$ applied during the FPN-3 and FPN-4 events was estimated from the irrigation volume applied and the fertilizer injection rate. Based on these methods, a total of $4.8,2.9,2.5$, and $7.3 \mathrm{~kg}$ $\mathrm{NO}_{3}-\mathrm{N}$ was applied during the FPN1, FPN-2, FPN-3, and FPN-4 events, respectively, and 17.1 and $37.1 \mathrm{~g}$ $\mathrm{NO}_{3}-\mathrm{N}$ for the BPN-1 and BPN-2 events, respectively.

The study area size varied depending on the event due to the plant production schedules at each nursery (i.e., production areas without plants received no irrigation or fertigation by turning off irrigation zones). The FPN- 1 and FPN-2 events collected runoff water from the entire production area, whereas the FPN-3 and FPN-4 events focused on a defined portion of the whole house. The production area for each nursery and for each event is listed in Table 1. Depending on the sampling event, runoff from the FPN occurred through two or three discharge pipes. All discharge events at the BPN were monitored at two discrete drainage pipes. Irrigation timing and volume applied varied depending on plant needs and production schedules. The irrigation systems at both nurseries were divided into multiple zones.

Discharge measurements. Three 10-inch-diameter PVC discharge pipes drained the FPN study area, while a 4- and 6-inch PVC discharge pipe drained the BPN study area. V-notch weirs were constructed and used at both nursery sites to estimate the instantaneous and cumulative flow volumes of runoff water during monitored events. The weirs were constructed of matching diameter (FPN: 10-inch, BPN: 4- and 6inch) PVC pipe by cutting a v-notch into one end of the pipe at angles varying from $30^{\circ}$ to $60^{\circ}$. Plexiglas panels with a thickness of $5 \mathrm{~mm}$ were marked at $1-\mathrm{cm}$ intervals and glued with clear silicon to each side of the vnotch. The constructed v-notch weirs were attached to $90^{\circ}$ elbows, which were attached to the downstream end of each discharge pipe evaluated. To estimate discharge volumes during monitored events, a flow rate versus depth of flow (through each weir) relationship was derived by regression analysis. Each weir was manually calibrated at $1-\mathrm{cm}$ depth increments throughout the useable range by regressing the depth within each vnotch against the measured flow rate (liters per minute). The $r^{2}$ for the best-fit exponential models for calibration were all greater than 0.99 . The weir calibrations were checked before each irrigation or fertigation event to confirm accuracy.

During runoff events, water depth readings were taken every 5 $\mathrm{min}$, and the flow in liters per minute was calculated using the regression equation determined during each weir's calibration. The total amount of water discharged through each pipe during the irrigation/fertigation event was calculated by averaging the flows every $5 \mathrm{~min}$. The average flow was then multiplied by the time ( 5 $\min$ ) to determine the water volume discharged during each 5-min interval. Water discharge volumes for each 5 -min interval for the entire duration of the runoff event were summed to estimate total discharge per drainage 
Table 1. Summary of event characteristics and nitrate-nitrogen $\left(\mathrm{NO}_{3}-\mathrm{N}\right)$ concentrations for each irrigation runoff event monitored at a foliage plant nursery and a bedding plant nursery in southern Florida.

\begin{tabular}{|c|c|c|c|c|c|c|c|c|c|}
\hline \multicolumn{4}{|c|}{ Event characteristics } & \multirow{2}{*}{\multicolumn{6}{|c|}{$\mathrm{NO}_{3}-\mathrm{N}\left(\mathrm{mg} \cdot \mathrm{L}^{-1}\right)^{\mathrm{z}}$}} \\
\hline \multirow[b]{2}{*}{ Event } & \multirow{2}{*}{$\begin{array}{c}\text { Study } \\
\text { area (ha) }\end{array}$} & \multirow{2}{*}{$\begin{array}{c}\text { Time } \\
\text { monitored (min) }\end{array}$} & \multirow{2}{*}{$\begin{array}{l}\text { Discharge } \\
(\mathrm{L})^{\mathrm{y}}\end{array}$} & & & & & & \\
\hline & & & & $n^{\mathrm{x}}$ & Mean & SD & Median & Low & High \\
\hline \multicolumn{10}{|c|}{ Foliage plant nursery (FPN) } \\
\hline FPN-1 & 1.01 & 360 & 20,935 & 96 & 101.1 & 69.4 & 57.0 & 21.0 & 274.0 \\
\hline FPN-2 & 1.01 & 255 & 13,668 & 71 & 129.7 & 41.3 & 115.7 & 70.5 & 252.7 \\
\hline FPN-3 & 0.20 & 185 & 2,487 & 38 & 214.5 & 68.8 & 210.4 & 68.2 & 342.9 \\
\hline \multicolumn{10}{|c|}{ Bedding plant nursery (BPN) } \\
\hline BPN-1 & 0.11 & 320 & 7,523 & 64 & 14.6 & 5.7 & 15.0 & 2.0 & 26.3 \\
\hline BPN-2 & $0.11^{\mathrm{w}}$ & 400 & 9,966 & 65 & 5.9 & 2.5 & 6.2 & 0.7 & 10.0 \\
\hline
\end{tabular}

${ }^{\mathrm{z}} \mathrm{l} \mathrm{mg} \cdot \mathrm{L}^{-1}=1 \mathrm{ppm}, \mathrm{l}$ ha $=2.4711$ acres.

'Discharge $=$ sum of all drainage pipes; $1 \mathrm{~L}=0.2645 \mathrm{gal}$.

${ }^{x}$ Number of samples.

wDrainage area actually was larger. Runoff from another zone began draining through the same pipes toward the end of the monitored event.

pipe during the monitored periods. Total discharge from the production area was estimated by summing the total volume for each pipe during the monitored period.

SAMPLING. Water samples for $\mathrm{NO}_{3}-\mathrm{N}$ analysis were collected directly from the discharge stream after passing through the weir. Sample collection began at the beginning of discharge and continued at $10-\mathrm{min}$ intervals through the duration of the monitored portion of each event.

Analysis. Water samples collected during runoff events were centrifuged (Marathon 21K/BR centrifuge; Fisher Scientific, Pittsburgh) for $5 \mathrm{~min}$ at $1612 \mathrm{~g}_{n}$ to remove any suspended solids; the supernatant was retained for $\mathrm{NO}_{3}-\mathrm{N}$ analysis. Nitratenitrogen was analyzed in all samples using the $\mathrm{NO}_{3}-\mathrm{N}$ ultraviolet spectrophotometric screening method (Clesceri et al., 1998). Briefly, $100 \mu \mathrm{L}$ of $1 \mathrm{~N}$ hydrochloric acid $(\mathrm{HCl})$ was added to $5 \mathrm{~mL}$ of each centrifuged sample to prevent interference from hydroxides and carbonates. Nitrate absorbance at $220 \mathrm{~nm}$ was measured in each sample using a Cary model 300 Bio ultraviolet-visible spectrophotometer (Varian, Walnut Creek, CA). To account for possible interference from dissolved organic materials, light absorbance was also measured at $275 \mathrm{~nm}$ as described. The corrected ultraviolet absorbance (abs) of $\mathrm{NO}_{3}-\mathrm{N}$ in the sample was calculated using the following equation: abs(corrected) $=$ abs $220 \mathrm{~nm}$ - (2) (abs $275 \mathrm{~nm})$. Results from the $\mathrm{NO}_{3}-\mathrm{N}$ screening method were confirmed using a discrete auto-analyzer (Smartchem Discrete
Analyzer; Westco Scientific Instruments, Brookfield, CT) and the USEPA method 353.2 for colorimetric determination of $\mathrm{NO}_{3}-\mathrm{N}$ (USEPA, 1993a). Results were also confirmed by ion chromatography (ICS-1000; Dionex, Sunnyvale, CA) using an Ion Pac AS14 anion separation column operating under conditions outlined in the USEPA method 300.0 (USEPA, 1993b).

ESTIMATION OF LOADINGS AND statistics. Nitrate-nitrogen loadings were estimated using the following equation: loading (milligrams) $=$ concentration (milligrams per liter $) \times$ volume (liters) discharged during each time interval. Cumulative loadings were estimated by adding interval-loadings together for the entire monitored portion of each event. Correlations between cumulative discharge volume (liters) and cumulative $\mathrm{NO}_{3}-\mathrm{N}$ loading (grams) during each event were identified using least squares linear regression models fit to the data $(P=0.05)$ for each individual event and for all of the FPN and BPN events combined, respectively. Correlations and models were fit using the analysis tool pack in Excel 97-2003 (Microsoft, Redmond, WA).

\section{Results and discussion}

A summary of the runoff volume and $\mathrm{NO}_{3}-\mathrm{N}$ concentrations is shown in Table 1. During the FPN-1 and FPN-2 events monitoring the entire l-ha production area, a total of 20,935 and $13,668 \mathrm{~L}$ of irrigation drainage water was discharged, respectively. A total of 2487 and $9454 \mathrm{~L}$ was discharged during the monitored portion of the FPN-3 and FPN-4 events. These losses equate to 12,391 and $47,105 \mathrm{~L} \cdot \mathrm{ha}^{-1}$, respectively. Total discharges during the BPN-1 and BPN-2 events were 7523 and 9966 $\mathrm{L}$, respectively, corresponding to losses of 67,169 and $88,982 \mathrm{~L} \cdot \mathrm{ha}^{-1}$. Maximum flow rates at the individual drains serving the study areas at both nurseries ranged from 59.2 to 126 $\mathrm{L} \cdot \mathrm{min}^{-1}$.

$\mathrm{NO}_{3}-\mathrm{N}$ concentrations ranged from 21.0 to $386.4 \mathrm{mg} \cdot \mathrm{L}^{-1}$ during the four monitored events at the FPN, and ranged from 0.7 to 26.3 $\mathrm{mg} \cdot \mathrm{L}^{-1}$ during the two BPN monitored events (Table 1 ). Total cumulative $\mathrm{NO}_{3}-\mathrm{N}$ loads discharged during each event varied. Loads discharged during the FPN-1, FPN-2, FPN-3, and FPN-4 events were $3024,1992,483$, and $2017 \mathrm{~g} \mathrm{NO}_{3}^{-}$ $\mathrm{N}$, respectively (Fig. 1). These losses equate to $63 \%, 68 \%, 19 \%$, and $27 \%$ of the amount applied during each respective event. $\mathrm{NO}_{3}-\mathrm{N}$ loads at the $\mathrm{BPN}$ were $11 \mathrm{l}$ and $5 \mathrm{lg}$, respectively, (Fig. 2). More $\mathrm{NO}_{3}-\mathrm{N}$ was discharged during the BPN events than was applied, possibly reflecting leaching losses from fertilizer that was incorporated into the media at planting. Additionally, some mixing of runoff water from other production areas at the BPN was apparent during both events, especially during the BPN-2 event. In nearly all of the individually monitored cases at the BPN and FPN, loadings were highly correlated $(r \geq$ 0.989 ) with the cumulative volume of water discharged (Table 2), indicating that losses were continuous as opposed to pulsed in nature. The 

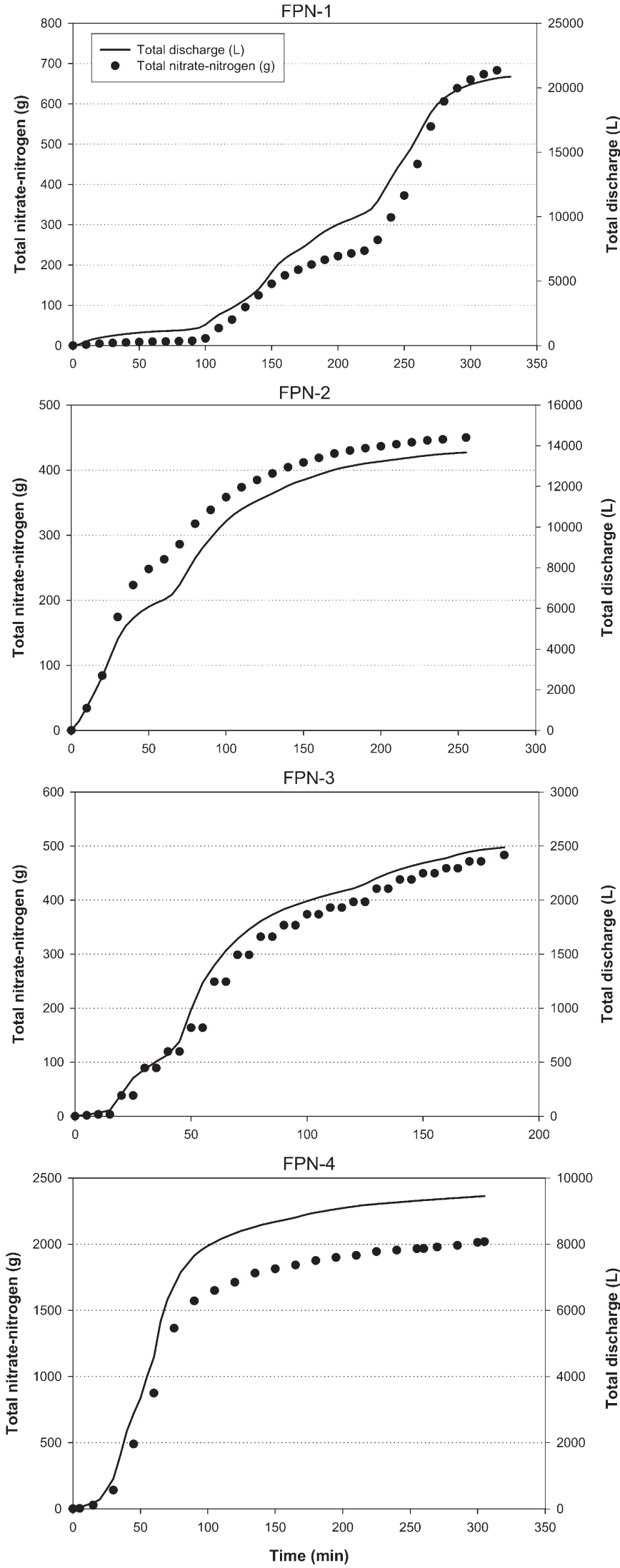

Fig. 1. Cumulative nitrate-nitrogen loads and cumulative volume of water discharged from a foliage plant nursery (FPN) production area in southern Florida during four fertigation events; $1 \mathrm{~g}=0.0353 \mathrm{oz}, 1 \mathrm{~L}=0.2642 \mathrm{gal}$. slopes for all of the FPN events ranged from 0.139 to $0.214 \mathrm{~g} \mathrm{NO}_{3}-\mathrm{N}$ per cumulative volume of discharge (liters). The slopes for the BPN individual events were 0.015 and $0.005 \mathrm{~g}$ $\mathrm{NO}_{3}-\mathrm{N}$ per cumulative volume of discharge (liters). It should be noted that the BPN-1 event included fertigation, whereas the BPN-2 event only included irrigation. The only event with a correlation coefficient ( $r$ ) less than 0.989 occurred with the BPN-2 event $(r=0.958)$. In this case, irrigation drainage water from another zone (outside of the monitored area) began draining through the same discharge path, resulting in a rapid increase in volume and associated $\mathrm{NO}_{3}-\mathrm{N}$ loading. Regression models fit to the combined FPN events were less precise relative to those of individual events as indicated by $\mathrm{R}^{2}=$ 0.909 . However, this model may provide a better overall prediction for other events in the absence of monitoring because it includes data from four separate events. These predictions are only valid for similar nursery/ fertigation situations (e.g., similar fertigation rates, volumes, production space, groundcoverings, etc.). The regression model fit to the BPN-1 and BPN-2 events combined did not fit well enough $\left(R^{2}=0.355\right)$ to be useful for predicting losses during other events. This lack of fit resulted from the BPN applying fertigation during one event and water-only during the other event.

Irrigation and fertilization management practices vary greatly between nurseries due to the diversity of crop species and sizes, differences in climate, management philosophies, crop scheduling, and marketing objectives. Thus, $\mathrm{NO}_{3}-\mathrm{N}$ application, use efficiencies, and contributions to surface water enrichment are expected to vary significantly between nurseries. While useful comparisons of application efficiency and $\mathrm{NO}_{3}-\mathrm{N}$ losses in runoff water between nurseries are difficult due to the differences mentioned, it is useful to have an appreciation for the diversity of expected losses under different systems. $\mathrm{NO}_{3}{ }^{-}$ $\mathrm{N}$ losses and concentrations at the FPN were much higher than those reported for other nurseries. Losses ranged from 1.9 to $10.1 \mathrm{~kg} \cdot \mathrm{ha}^{-1}$ per event. Assuming one fertigation event per week, these losses would equate to 98.8 to $525.2 \mathrm{~kg} \cdot \mathrm{ha}^{-1}$ per year. 

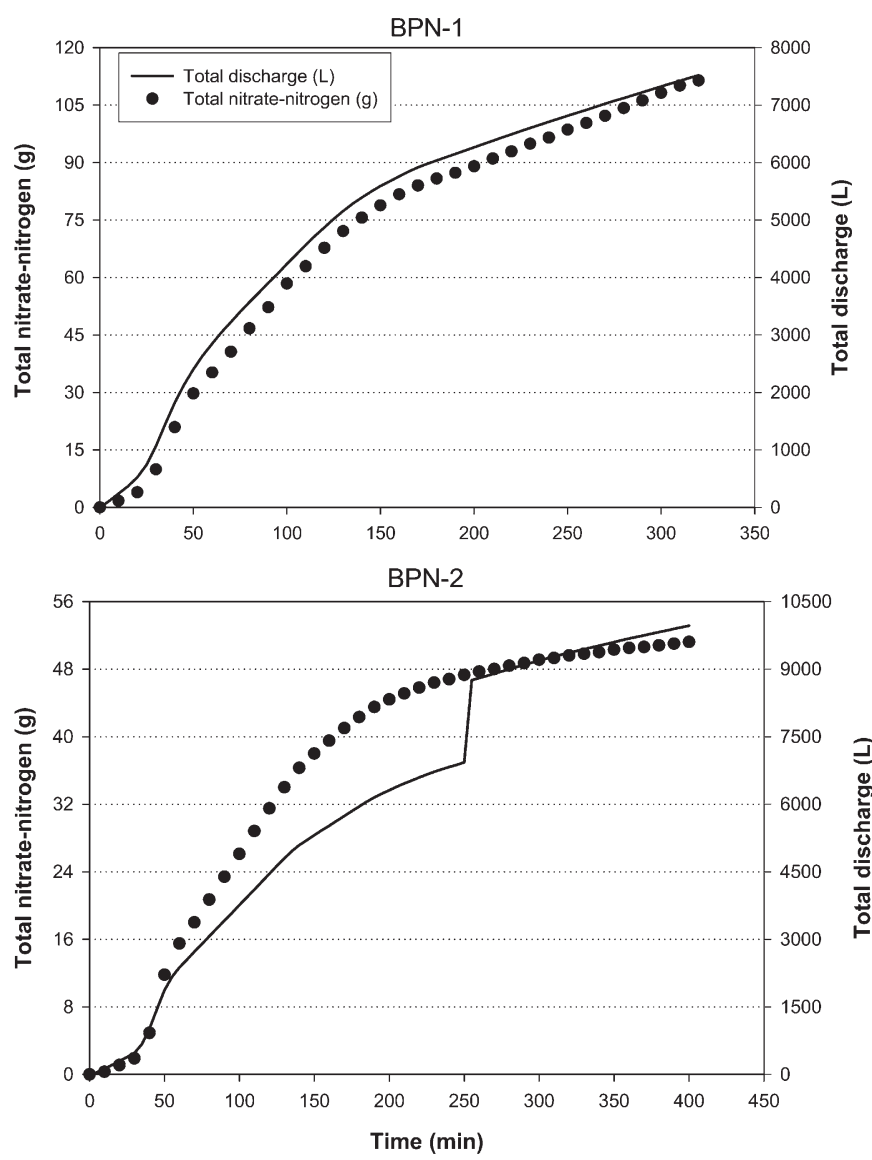

Fig. 2. Cumulative nitrate-nitrogen loads and cumulative volume of water discharged from a bedding plant nursery (BPN) production area in southern Florida during two irrigation/fertigation events; $1 \mathrm{~g}=0.0353 \mathrm{oz}, 1 \mathrm{~L}=0.2642 \mathrm{gal}$.

Table 2. Correlation coefficient $(R)$, regression coefficient $\left(R^{2}\right)$, and model coefficients [slope $(\mathrm{m})$ and intercept $(\mathrm{b})$ ] for linear models fit to the cumulative loads of nitrate-nitrogen $\left(\mathrm{NO}_{3}-\mathrm{N}\right)$ versus cumulative flow for each irrigation / fertigation event monitored at a foliage plant nursery and bedding plant nursery in southern Florida.

\begin{tabular}{|c|c|c|c|c|}
\hline Event & $\mathbf{R}^{\mathbf{z}}$ & $\mathbf{R}^{2 \mathrm{z}}$ & Slope & Intercept $\mathrm{t}^{\mathrm{y}}$ \\
\hline \multicolumn{5}{|c|}{ Foliage plant nursery (FPN) } \\
\hline FPN-1 & 0.989 & 0.978 & 0.141 & -154.7 \\
\hline FPN-2 & 0.991 & 0.983 & 0.139 & 123.5 \\
\hline FPN-3 & 0.995 & 0.991 & 0.192 & -12.3 \\
\hline FPN-4 & 0.999 & 0.998 & 0.214 & -45.1 \\
\hline FPN 1-4 (combined) & 0.953 & 0.909 & 0.146 & 62.2 \\
\hline \multicolumn{5}{|c|}{ Bedding plant nursery (BPN) } \\
\hline BPN-1 & 0.998 & 0.997 & 0.015 & -5.4 \\
\hline BPN-2 & 0.958 & 0.918 & 0.005 & 5.5 \\
\hline BPN 1-2 (combined) & 0.603 & 0.355 & 0.006 & 14.6 \\
\hline
\end{tabular}

${ }^{\mathrm{z}} P=0.05$.

y Regression equation: cumulative $\mathrm{NO}_{3}-\mathrm{N}$ in grams $=\mathrm{m}$ (cumulative discharge in liters) $+\mathrm{b} ; \mathrm{lg}=0.0353 \mathrm{oz}$, $1 \mathrm{~L}=0.2642 \mathrm{gal}$.

Colangelo and Brand (2001) reported annual production area $\mathrm{NO}_{3}-\mathrm{N}$ losses of 51.8 to $60.5 \mathrm{~kg} \cdot \mathrm{ha}^{-1}$ for 'Album' rhododendron crops potted in $3.2-\mathrm{L}$ containers and irrigated with overhead and trickle systems. Plants in their study were fertilized with a controlled- et al., 2006), and 0.1 to $135 \mathrm{mg} \cdot \mathrm{L}^{-1} \mathrm{~N}$ (Yeager et al., 1993). $\mathrm{NO}_{3}-\mathrm{N}$ losses in runoff water from production areas represent less than optimal production efficiency, contributing to higher than necessary production costs and increased potential for surface water degradation due to $\mathrm{NO}_{3}-\mathrm{N}$ enrichment.

The higher $\mathrm{NO}_{3}-\mathrm{N}$ losses, volume, and concentration from the FPN were likely due to their almost total reliance on fertigation (i.e., soluble fertilizer) for fertility maintenance. For fertigation events, the soluble fertilizer injection system employed resulted in the application of fertilizer for the entire irrigation event, including the FPN's target leaching fraction. This resulted in fertigation solution passing directly through the pot and into the runoff stream. In this case, overirrigation would greatly amplify nutrient losses. One possible solution for reducing these excess discharges associated with fertigation may be to configure irrigation and fertigation systems to allow irrigation and leaching of substrates for the first portion of the event, with a switch to fertigation at the end. In this case, fertigation would only be applied to the point of refilling the pot, minimizing excess leaching of the fertigation solution.

These results also have great implications for the design of a microbial-based denitrifying bioremediation system. With such a system, microflora must be provided with a source of available carbon, in addition to the $\mathrm{NO}_{3}-\mathrm{N}$ (Matějů et al., 1992). Under optimal conditions, these microflora convert $\mathrm{NO}_{3}-\mathrm{N}$ to di-nitrogen gas $\left(\mathrm{N}_{2}\right)$. The variability in $\mathrm{NO}_{3}-\mathrm{N}$ concentrations observed during each FPN and BPN event and the previously published reports for other nurseries and crops indicate that the dosing rate for carbon sources should not be based on a single representative $\mathrm{NO}_{3}-\mathrm{N}$ concentration. For optimal carbon dosing and efficiency, the system should adjust to real-time $\mathrm{NO}_{3}-\mathrm{N}$ concentrations or surrogate indicator conditions (e.g., oxidation-reduction potential) (Matějù et al., 1992). Additionally, substrates employed for microflora attachment must be highly porous to accommodate the discharge volumes and rates measured in these studies.

In conclusion, these results indicate that significant amounts of 
$\mathrm{NO}_{3}-\mathrm{N}$ can leave nursery production sites in runoff water associated with drip and overhead irrigation and fertigation practices. Likewise, it can be assumed that rainfall events causing drainage through pots and surface runoff from the production areas may result in similar losses. $\mathrm{NO}_{3}-\mathrm{N}$ concentrations in the majority of the samples collected during the runoff events exceeded the $10-\mathrm{mg} \cdot \mathrm{L}^{-1}$ drinking water limit set by the USEPA. These high levels indicate a need for remedial action if the drainage water interacts with drinking water sources. In addition, remedial action may also be needed to prevent adverse effects to $\mathrm{N}$-limited natural water bodies, depending on local and state regulations. With regard to the overall project objective of developing a bioremediation system for removing $\mathrm{NO}_{3}-\mathrm{N}$ from plant nursery surface drainage water, this project provided valuable information regarding realistic loadings and flow rates that must be considered.

\section{Literature cited}

Alexander, S. 1993. Pollution control and prevention at containerized nursery operations. Water Sci. Technol. 28:509-517.
Bigelow, C., D. Bowman, and D. Cassel. 2001. Nitrogen leaching in sand-based root zones amended with inorganic soil amendments and sphagnum peat. J. Amer. Soc. Hort. Sci. 126:151-156.

Clesceri, L.S., A.E. Greenberg, and A.D. Eaton. 1998. NO3-N ultraviolet spectrophotometric screening method, p. 249250. In: Standard methods for the examination of water and wastewater. 20th ed. American Public Health Assn., Washington, DC.

Colangelo, D.J. and M.H. Brand. 2001. Nitrate leaching beneath a containerized nursery crop receiving trickle or overhead irrigation. J. Environ. Qual. 30:15641574 .

Mangiafico, S.S., J. Newman, D.J. Merhaut, J. Gan, B. Faber, and L. Wu. 2009. Nutrients and pesticides in stormwater runoff and soil water in production nurseries and citrus and avocado groves in California. HortTechnology 19:360-367.

Matějů, V., S. Čižinská, J. Krejččí, and T. Janoch. 1992. Biological water denitrification: A review. Enzyme Microb. Technol. 14:170-183.

Merhaut, D.J., E.K. Blythe, J.P. Newman, and J.P. Albano. 2006. Nutrient release from controlled-release fertilizers in acid substrate in a greenhouse environment: I.
Leachate electrical conductivity, $\mathrm{pH}$, and nitrogen, phosphorus, and potassium concentrations. HortScience 41:780787.

Taylor, M.D., S.A. White, S.L. Chandler, S.J. Klaine, and T. Whitwell. 2006. Nutrient management of nursery runoff water using constructed wetland systems. HortTechnology 16:610-614.

U.S. Environmental Protection Agency. 1993a. Method 353.2: Determination of nitrate-nitrite nitrogen by automated colorimetry. Rev. 2. 8 Sept. 2009. <http:// www.epa.gov/waterscience/methods/ method/files/353_2.pdf>.

U.S. Environmental Protection Agency. 1993b. Method 300.0: Determination of inorganic anions by ion chromatography. Rev. 2.1. 8 Sept. 2009. <http://www. epa.gov/waterscience/methods/method/ files /300_0.pdf>.

Yeager, T., R. Wright, D. Fare, C. Gilliam, J. Johnson, T. Bilderback, and R. Zondag. 1993. Six state survey of container nursery nitrate nitrogen runoff. J. Environ. Hort. 11:206-208. 